\title{
Ekstrak Metanol Biji Asam Jawa (Tamarindus Indica) Memperbaiki Kerusakan Histopatologi Ginjal Tikus yang Diinduksi Aluminium
}

\author{
Anang Dwi Atmoko ${ }^{1}$, Al Munawir ${ }^{2}$, Ika Rahmawati Sutejo ${ }^{3}$ \\ Fakultas Kedokteran Universitas Jember ${ }^{1}$ \\ Fakultas Kedokteran Universitas Jember ${ }^{2}$ \\ Fakultas Kedokteran Universitas Jember ${ }^{3}$ \\ *e-mail: ikarahmawati.fk@unej.ac.id
}

\begin{abstract}
Abstrak
Aluminium merupakan logam paling banyak digunakan dalam kehidupan sehari-hari dan paparan aluminium yang berlebihan dapat terakumulasi pada sel tubulus ginjal, bersifat nefrotoksik sehingga dapat memicu degenerasi sel tubulus melalui mekanisme stres oksidatif. Biji Tamarindus indica mengandung senyawa polifenol dan potensi antioksidan tinggi. Tujuan penelitian ini untuk mengetahui apakah ekstrak metanol biji Tamarindus indica dapat memperbaiki kerusakan histopatologi ginjal tikus yang diinduksi aluminium dinilai dari parameter degenerasi dan nekrosis sel tubulus. Penelitian ini dilakukan di Fakultas Kedokteran Universitas Jember selama 10 minggu dengan menggunakan 30 ekor tikus wistar jantan. Tikus dibagi dalam 5 kelompok; 1) K: kelompok kontrol diberikan larutan campuran aquabidessaline, 2) $\mathrm{K}(-)$ : kelompok kontrol negatif diberikan larutan garam aluminium $\left.\left(\mathrm{AlCl}_{3}\right), 3\right) \mathrm{P} 1$ : kelompok perlakuan 1 diberikan larutan garam aluminium $\left(\mathrm{AlCl}_{3}\right)$ dan ekstrak dosis 25 $\mathrm{mg} / \mathrm{kgBB}, 4) \mathrm{P} 2$ : kelompok perlakuan 2 diberikan larutan garam aluminium $\left(\mathrm{AlCl}_{3}\right)$ dan ekstrak dosis $50 \mathrm{mg} / \mathrm{kgBB}, 5) \mathrm{P3}$ : kelompok perlakuan 3 diberikan larutan garam aluminium $\left(\mathrm{AlCl}_{3}\right)$ dan ekstrak dosis $100 \mathrm{mg} / \mathrm{kgBB}$. Larutan garam aluminium $\left(\mathrm{AlCl}_{3}\right)$ diberikan dalam dosis 300 $\mathrm{mg} / \mathrm{kgBB}$. Setelah terminasi, preparat ginjal tikus dilakukan proses scoring kerusakan. Hasil skor berdasarkan parameter degenerasi sel semua kelompok tikus mendapatkan skor kerusakan 5. Hasil skor berdasarkan parameter nekrosis sel terdapat variasi skor antarkelompok. Berdasarkan parameter nekrosis, ekstrak metanol biji Tamarindus indica memperbaiki kerusakan jaringan ginjal tikus yang diinduksi aluminium.
\end{abstract}

Kata Kunci: Tamarindus indica, ginjal, aluminium, stres oksidatif, antioksidan

\section{Methanolic Extract of Asam Jawa (Tamarindus indica) Seed Repair Histopathological Damage of Rat Kidney Induced by Aluminum}

\begin{abstract}
Aluminum is the most widely used metal in everyday and the exposure of aluminum can be accumulate in kidney tubular cells, which cause tubular cell degeneration through oxidative stress because of nephrotoxicity. Tamarindus indica seeds contain high polyphenolic compounds and high antioxidant potential. This study aimed to investigate whether the methanolic extract of Tamarindus indica seeds repair histopathological damage of aluminuminduced kidney rat assessed by the parameters of tubular cell degeneration and necrosis. This experimental study was conducted at the Faculty of Medicine, University of Jember for 10 weeks using 30 male Wistar rats. Rats were divided into 5 groups; 1) K: control group was given a mixture of aquabides-saline ( $\mathrm{NaCl} 0.9 \%), 2) \mathrm{K}(-)$ : negative control group was given aluminum
\end{abstract}


Ekstrak Metanol Biji Asam Jawa (Tamarindus Indica) Memperbaiki Kerusakan Histopatologi... Anang Dwi Atmoko, Al Munawir, Ika Rahmawati Sutejo

solution $\left(\mathrm{AlCl}_{3}\right)$, 3) P1: first treatment group was given aluminum solution $\left.(\mathrm{AlCl})_{3}\right)$ and extract (25 mg/kg b.w., po), 4) P2: second treatment group was given aluminum solution $\left(\mathrm{AlCl}_{3}\right)$ and extract (50 mg/kg b.w., po), 5) P3: third treatment group was given aluminum solution $\left(\mathrm{AlCl}_{3}\right)$ and extract (100 mg/kg b.w., po). Aluminum solution is given in a dose of $300 \mathrm{mg} / \mathrm{kg} \mathrm{b.w.} \mathrm{po.}$ After being terminated, the rat's kidney histology were examined to a scoring damage process. Based on cell degeneration parameter, all groups get 5 in score of damage. Meanwhile based on cell necrosis parameter, all group get different score of damage. Based on the cell necrosis parameter, the methanolic extract of Tamarindus indica seeds repair histopathological damage of rat kidney induced by aluminum chloride.

Keywords: Tamarindus indica, kidney, aluminium, oxidative stress, antioxidant

\section{PENDAHULUAN}

Aluminium merupakan logam paling melimpah nomor 3 di alam, dan terdapat sekitar $8 \%$ di permukaan bumi (Dolara, 2014). Aluminium menjadi logam yang paling banyak dimanfaatkan dalam kehidupan sehari-hari seperti penggunaan aluminium dalam pemurnian air, penggunaan aluminium sebagai bahan perabotan rumah tangga, sehingga sumber paparan aluminium pada manusia juga beragam. Tubuh manusia dapat terpapar oleh aluminium melalui makanan, minuman, obat, dan debu di udara (Vignal et al, 2016). Aluminium masuk dalam tubuh manusia dapat terakumulasi dan bersifat nefrotoksik, sehingga dapat memicu degenerasi sel tubulus ginjal (Dera, 2016; Kahtani et al, 2014). Mekanisme nefrotoksik yang ditimbulkan aluminium melalui stres oksidatif yang menyebabkan kerusakan pada lipid seluler, protein, dan DNA (Dera, 2016).
Biji Tamarindus indica merupakan salah satu bahan alam yang dapat dimanfaatkan sebagai sumber antioksidan. Biji Tamarindus indica memiliki kandungan senyawa polifenol lebih tinggi dibanding biji lain (Cunglok et al, 2014). Ekstrak metanol biji Tamarindus indica memiliki kandungan senyawa polifenol dan potensi antioksidan lebih tinggi dibanding ekstrak metanol bagian lain dari tanaman Tamarindus indica (Razali et al, 2015). Senyawa polifenol dalam ekstrak metanol biji Tamarindus indica mampu melindungi sel HepG2 hepar manusia terhadap peroksidasi lipid melalui mekanisme sebagai agen pereduksi, penangkap radikal bebas, dan meningkatkan aktivitas enzim antioksidan (Razali et al, 2015). Ekstrak metanol biji Tamarindus indica mengandung senyawa procyanidin B2, myricetin dan caffeic acid yang memiliki potensi antiinflamasi dan antioksidan (Narwanto, 2018). 
ISSN 1978-2071 (Print); ISSN 2580-5967 (Online) Jurnal IImiah Kedokteran Wijaya Kusuma 9(2) : 180-189, September 2020

Berdasarkan latar belakang tersebut, peneliti tertarik untuk mengetahui apakah ekstrak metanol biji Tamarindus indica dapat memperbaiki kerusakan jaringan ginjal tikus yang diinduksi aluminium dinilai dari parameter degenerasi dan nekrosis sel tubulus. Tujuan dari penelitian ini adalah untuk mengetahui apakah pemberian ekstrak metanol biji Tamarindus indica memperbaiki kerusakan jaringan ginjal tikus yang diinduksi aluminium dinilai dari parameter degenerasi dan nekrosis sel tubulus.

\section{BAHAN DAN METODE}

Penelitian eksperimental dilakukan di Fakultas Kedokteran dengan menggunakan 30 ekor tikus Wistar jantan yang berusia 23 bulan dengan berat badan $\pm 200 \mathrm{gr}$, sehat yang ditunjukkan dengan bergerak aktif. Tikus ditempatkan dalam kandang yang berisi 1 ekor tikus tiap kadang. Proses aklitimasi tikus dilakukan dalam waktu 7 hari. Selama penelitian berlangsung, tikus diberi pakan dan minum secara ad libitum dengan pembersihan kandang dan penggantian serbuk kayu setiap seminggu sekali. Pemberian larutan campuran aquabides-saline, larutan garam aluminium $\left(\mathrm{AlCl}_{3}\right)$ dan larutan ekstrak diberikan setiap hari peroral selama 10 minggu.

Setelah proses aklitimasi selama seminggu, tikus dibagi secara acak kedalam
5 kelompok penelitian. Kelompok $\mathrm{K}$ atau kontrol diberikan larutan campuran aquabides-saline $1 \mathrm{~mL}$; Kelompok K(-) atau kontrol negatif diberikan larutan garam aluminium $\left(\mathrm{AlCl}_{3}\right)$ dosis $300 \mathrm{mg} / \mathrm{kgBB}$; Kelompok P1 atau perlakuan 1 diberikan larutan garam aluminium $\left(\mathrm{AlCl}_{3}\right)$ dosis 300 $\mathrm{mg} / \mathrm{kgBB}$ dan larutan ekstrak biji Tamarindus indica dosis $25 \mathrm{mg} / \mathrm{kgBB}$; Kelompok P2 atau perlakuan 2 diberikan larutan garam aluminium $\left(\mathrm{AlCl}_{3}\right)$ dosis 300 $\mathrm{mg} / \mathrm{kgBB}$ dan larutan ekstrak biji Tamarindus indica dosis $50 \mathrm{mg} / \mathrm{kgBB}$; Kelompok P3 atau perlakuan 3 diberikan larutan garam $\left(\mathrm{AlCl}_{3}\right)$ aluminium dosis 300 $\mathrm{mg} / \mathrm{kgBB}$ dan larutan ekstrak biji Tamarindus indica dosis $100 \mathrm{mg} / \mathrm{kgBB}$.

\section{Ekstraksi}

Ekstraksi biji Tamarindus indica menggunakan teknik maserasi. Biji Tamarindus indica kering dihaluskan dan dibuat serbuk. Serbuk biji Tamarindus indica $(100 \mathrm{mg})$ direndam dalam cairan metanol $(500 \mathrm{~mL}$ ) selama 72 jam pada suhu ruangan dan dilakukan pengadukan secara periodik. Hasil rendaman disaring dalam 2 kali penyaringan dan dievaporasi menggunakan water bath untuk mendapatkan residu ekstrak (Bandawane et al, 2013).

Larutan campuran aquabides-saline dibuat dengan mencampurkan aquabides dan saline $(\mathrm{NaCl} \quad 0,9 \%)$ dengan 
Ekstrak Metanol Biji Asam Jawa (Tamarindus Indica) Memperbaiki Kerusakan Histopatologi... Anang Dwi Atmoko, Al Munawir, Ika Rahmawati Sutejo

perbandingan 1:1. Larutan garam aluminium $\left(\mathrm{AlCl}_{3}\right)$ dibuat dengan mencampurkan serbuk $\mathrm{AlCl}_{3}$ dengan aquabides, hingga didapatkan konsentrasi $50 \mathrm{mg} \mathrm{AlCl}_{3}$ dalam $1 \mathrm{~mL}$ aquabides. Larutan ekstrak dibuat dengan mencampurkan ekstrak biji Tamarindus indica dan larutan saline $(\mathrm{NaCl} 0,9 \mathrm{~mL})$ sesuai jumlah yang dibutuhkan hingga konsentrasi $50 \mathrm{mg}$ ekstrak dalam $1 \mathrm{~mL}$ saline ( $\mathrm{NaCl} 0,9 \mathrm{~mL})$.

Setelah masa perlakuan 10 minggu, seluruh tikus diterminasi dengan melakukan proses anestesi menggunakan eter dan dilanjutkan dislokasi servikal. Ginjal kanan tikus diambil, kemudian dilakukan pencucian dalam larutan saline ( $\mathrm{NaCl}$ 0,9\%) sebelum dimasukkan dalam wadah berisi larutan buffer normal formalin $10 \%$ dengan volume minimal 5 kali volume ginjal. Wadah diberikan label sesuai dengan kelompok penelitian.

\section{Evaluasi Histopatologi}

Ginjal tikus dari seluruh kelompok penelitian diproses untuk dibuat preparat histopatologi dengan pewarnaan Hematoxylin dan Eosin. Setiap preparat diamati menggunakan mikroskop cahaya Leica DM 500 dengan metode blinding, yaitu pengamat tidak mengetahui identitas asli setiap preparat dikarenakan identitas sudah disamarkan oleh orang lain dan perbesaran mikroskop 400 kali di 5 lapang pandang pengamatan. Parameter penilaian dalam pengamatan preparat meliputi degenerasi dan nekrosis sel etubulus. Skor yang diberikan adalah $0=0 \%$ kerusakan, 1 $=0-10 \%$ kerusakan, $2=11-25 \%$ kerusakan, $3=26-45 \%$ kerusakan, $4=46-75 \%$ kerusakan, $5=76-100 \%$ kerusakan (Kocoglu et al, 2009).

\section{Analisis Statistik}

Data dianalisis menggunakan program SPSS. Data hasil scoring merupakan data ordinal, sehingga analasis data menggunakan uji Kruskal Wallis yang dilanjutkan uji Post Hoc Mann Whitney apabila didapatkan nilai $p<0,05$.

\section{HASIL}

Hasil penelitian berupa skor kerusakan histopatologi ginjal dinilai dari parameter degenerasi dan nekrosis sel tubulus. Hasil pengamatan histopatologi semua kelompok dapat diamati pada Gambar 1. 

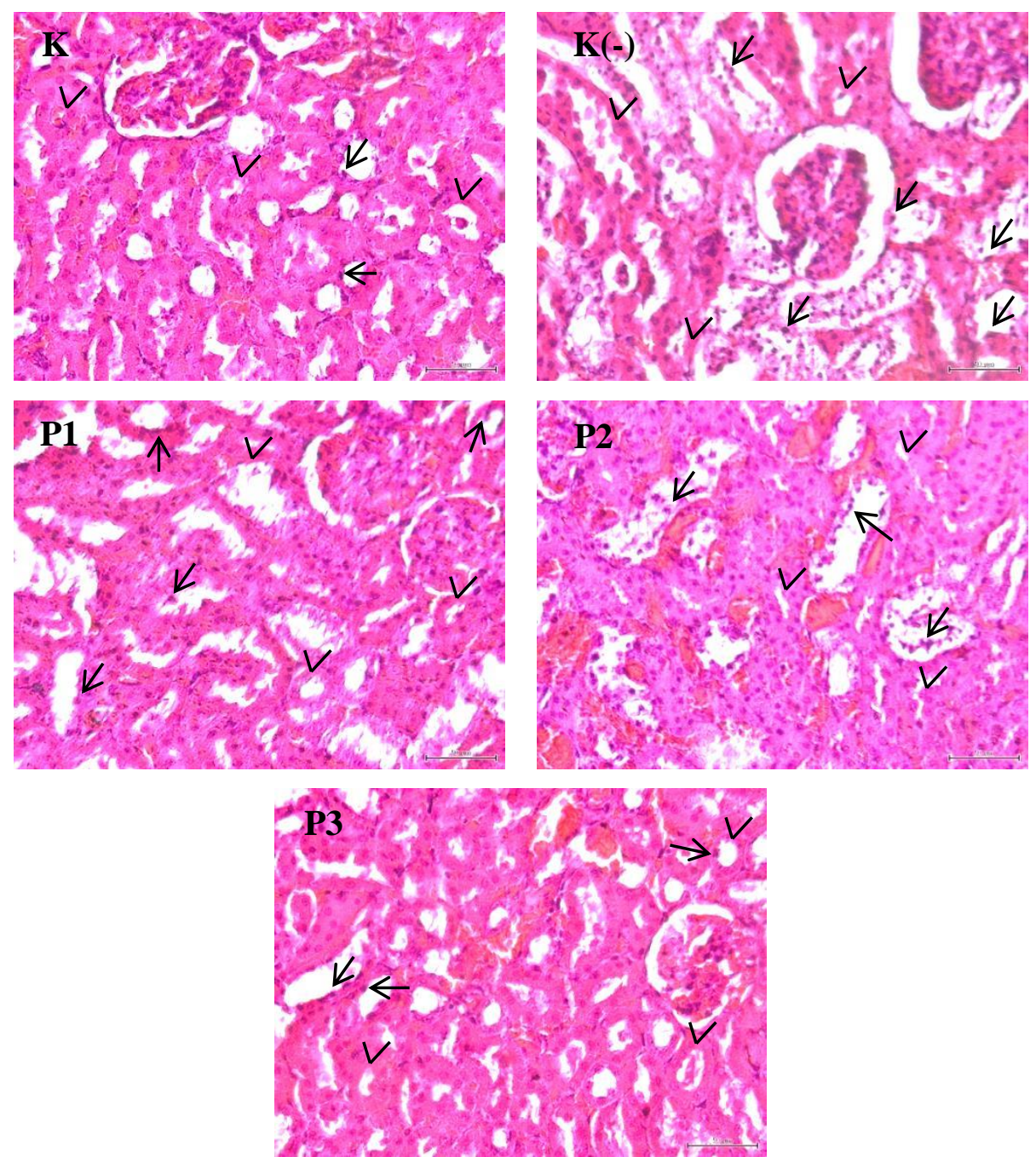

Gambar 1. Gambaran histopatologi dengan pewarnaan HE dan perbesaran 400x pada pengamatan dengan mikroskop cahaya Leica DM 500 dan optilab Olympus DP21. Tampak kerusakan berupa degenrasi tubulus (kepala panah) dan nekrosis tubulus (panah lurus)

Skor kerusakan histopatologi kerusakan histopatologi berdasarkan berdasarkan parameter degenerasi sel parameter nekrosis sel dapat diamati pada dapat diamati pada Tabel 1. Skor Tabel 2.

Tabel 1. Skor kerusakan parameter degenerasi sel

\begin{tabular}{ccccccc}
\hline Kelompok & \multicolumn{7}{c}{ Skor } \\
\cline { 2 - 6 } & $\mathbf{0}$ & $\mathbf{1}$ & $\mathbf{2}$ & $\mathbf{3}$ & $\mathbf{4}$ & $\mathbf{5}$ \\
\hline Kontrol & - & - & - & - & - & 5 ekor \\
Kontrol negatif & - & - & - & - & - & 5 ekor \\
Perlakuan 1 & - & - & - & - & - & 5 ekor \\
Perlakuan 2 & - & - & - & - & - & 5 ekor \\
Perlakuan 3 & - & - & - & - & - & 5 ekor \\
\hline
\end{tabular}


Ekstrak Metanol Biji Asam Jawa (Tamarindus Indica) Memperbaiki Kerusakan Histopatologi... Anang Dwi Atmoko, Al Munawir, Ika Rahmawati Sutejo

Tabel 2. Skor kerusakan parameter nekrosis sel

\begin{tabular}{ccccccc}
\hline Kelompok & \multicolumn{7}{c}{ Skor } \\
\cline { 2 - 7 } & $\mathbf{0}$ & $\mathbf{1}$ & $\mathbf{2}$ & $\mathbf{3}$ & $\mathbf{4}$ & $\mathbf{5}$ \\
\hline Kontrol & - & 2 ekor & 3 ekor & - & - & - \\
Kontrol negatif & - & - & - & 2 ekor & 3 ekor & - \\
Perlakuan 1 & - & - & - & 3 ekor & 2 ekor & - \\
Perlakuan 2 & - & - & 3 ekor & 2 ekor & - & - \\
Perlakuan 3 & - & 2 ekor & 3 ekor & - & - & - \\
\hline
\end{tabular}

Uji analisis Kruskal Wallis untuk parameter degenerasi sel didapatkan nilai $p=1(p>0,05)$, sehingga tidak dilanjutkan uji post hoc Mann Whitney. Uji analisis Kruskal Wallis untuk parameter nekrosis sel didapatkan nilai $p=0,001 \quad(p<0,05)$, yang artinya terdapat perbedaan bermakna antarkelompok. Uji dilanjutkan dengan uji post hoc Mann Whitney dan didapatkan nilai $\mathrm{p}$ bervariasi. Nilai $\mathrm{p}$ uji post hoc Mann Whitney dapat dilihat pada Tabel 3.

Tabel 3. Nilai $p$ uji post hoc Mann Whitney

\begin{tabular}{cccccc}
\hline Kelompok & $\mathrm{K}$ & $\mathrm{K}(-)$ & $\mathrm{P} 1$ & $\mathrm{P} 2$ & $\mathrm{P} 3$ \\
\hline $\mathrm{K}$ & & $0,008^{*}$ & $0,008^{*}$ & 0,095 & 1 \\
$\mathrm{~K}(-)$ & $0,008^{*}$ & & 0,69 & $0,032^{*}$ & $0,008^{*}$ \\
P1 & $0,008^{*}$ & 0,69 & & 0,056 & $0,008^{*}$ \\
P2 & 0,095 & $0,032^{*}$ & 0,056 & & 0,095 \\
P3 & 1 & $0,008^{*}$ & $0,008^{*}$ & 0,095 & \\
\hline
\end{tabular}

Keterangan: $\left({ }^{*}\right)$ terdapat perbedaan yang bermakna

Hasil analisis post hoc Mann Whitney antara kelompok K dengan kelompok K(-) $(p=0,008)$, kelompok K(-) dengan kelompok P2 $(p=0,032)$, kelompok $\mathrm{K}(-)$ dengan kelompok P3 $(p=0,008)$ menunjukkan nilai $p<0,05$ yang berarti terdapat perbedaan yang bermakna antara 2 kelompok tersebut. Hasil analisis post hoc Mann Whitney antara kelompok $\mathrm{K}(-)$ dengan kelompok $P 1(p=0,69)$ menunjukkan nilai $p>0,05$ yang berarti tidak terdapat perbedaan yang bermakna antara kedua kelompok tersebut.

\section{PEMBAHASAN}

Ginjal merupakan organ penting dalam tubuh yang berperan mengatur komposisi cairan tubuh supaya tetap stabil dan membuang sampah melalui proses ekskresi (Samawy, 2012). Aluminium dalam darah dapat terakumulasi pada sel tubulus ginjal dan dapat menyebabkan kerusakan pada sel tubulus (degenerasi dan nekrosis sel tubulus ginjal) melalui mekanisme stres oksidatif (Dera, 2016; Kahtani et al, 2014). Penelitian yang dilakukan oleh Tripathi et al, (2008) menunjukkan bahwa pemberian aluminium dosis $100 \mathrm{mg} / \mathrm{kg}$ BB peroral 
selama 90 hari dapat menyebabkan edema glomerulus dan degenerasi epitel tubulus.

Pemberian ekstrak metanol biji Tamarindus indica yang memiliki kandungan senyawa polifenol dan potensi antioksidan tinggi diharapkan mampu memperbaikiterjadinya stres oksidatif pada sel tubulus ginjal. Penelitian oleh VargasOlvera (2012) menunjukkan bahwa ekstrak biji Tamarindus indica dapat memperbaiki kerusakan histologi ginjal karena stres oksidatif yang ditimbulkan oleh $\mathrm{N}$ Diethylnitrosamine dan Ferric nitrilotriacetate. Penelitian lain oleh Razali et al, (2015) menunjukkan ekstrak biji Tamarindus indica memberikan perlindungan terhadap terjadinya stres oksidatif pada sel HepG2.

Pada penelitian ini, ekstrak metanol biji Tamarindus indica memperbaiki kerusakan sel tubulus dinilai dari parameter nekrosis. Kelompok perlakuan 1 yang diberikan aluminium dosis 300 $\mathrm{mg} / \mathrm{kgBB}$ dan ekstrak dosis $25 \mathrm{mg} / \mathrm{kgBB}$ menunjukkan skor kerusakan tidak berbeda dengan kelompok kontrol negatif yang hanya diberikan aluminium dosis 300 $\mathrm{mg} / \mathrm{kgBB}$. Ini menunjukkan pemberian ekstrak metanol biji Tamarindus indica dosis $25 \mathrm{mg} / \mathrm{kgBB}$ belum memberikan efek pencegahan terhadap kerusakan yang ditimbulkan aluminium. Hal ini dapat terjadi akibat konsentrasi kandungan senyawa polifenol dalam ekstrak metanol biji Tamarindus indica belum mencukupi untuk memberikan efek pencegahan terhadap kerusakan sel tubulus yang disebabkan aluminium. Penelitian oleh AlAni et al, (2017) menunjukkan pemberian ekstrak biji Tamarindus indica dosis 10 $\mathrm{mg} / 20$ grBB belum mampu memberikan efek perbaikan terhadap gambaran histopatologi ginjal tikus yang mengalami kerusakan oleh King Cobra Venom. Sedangkan kelompok perlakuan 2 dan kelompok perlakuan 3 yang diberikan aluminium dosis $300 \mathrm{mg} / \mathrm{kgBB}$ serta ekstrak metanol biji Tamarindus indica dosis 50 dan 100 mg/kgBB memperlihatkan adanya pencegahan terhadap kerusakan sel tubulus dibuktikan dengan skor kerusakan lebih rendah dibanding kelompok kontrol negatif yang hanya diberikan aluminium dosis $300 \mathrm{mg} / \mathrm{kgBB}$. Penelitian oleh Sundaram et al, (2014) menunjukkan pemberian ekstrak biji Tamarindus indica dosis $50 \mathrm{mg} / \mathrm{kgBB}$ mampu mengurangi pembentukan ROS endogen, mengurangi kadar $\mathrm{H}_{2} \mathrm{O}_{2}$ endogen, mengembalikan tingkat GSH, meningkatkan aktivitas enzim antioksidan dan menunjukkan tingkat peroksidasi lipid yang lebih rendah dibanding kelompok yang diinduksi rematik. Uji Post Hoc Mann Whitney antara kelompok ekstrak dosis 25 $\mathrm{mg} / \mathrm{kgBB}$ dengan kelompok ekstrak dosis 
Ekstrak Metanol Biji Asam Jawa (Tamarindus Indica) Memperbaiki Kerusakan Histopatologi... Anang Dwi Atmoko, Al Munawir, Ika Rahmawati Sutejo

$50 \mathrm{mg} / \mathrm{kgBB}$ dan kelompok ekstrak dosis 50 $\mathrm{mg} / \mathrm{kgBB}$ dengan kelompok ekstrak dosis $100 \mathrm{mg} / \mathrm{kgBB}$ menunjukkan tidak terdapat perbedaan yang bermakna antara dua kelompok tersebut. Kelompok ekstrak dosis 25, 50 dan $100 \mathrm{mg} / \mathrm{kgBB}$ memiliki skor kerusakan yang tidak jauh berbeda, meskipun terjadi penurunan skor kerusakan dari kelompok ekstrak dosis 25 $\mathrm{mg} / \mathrm{kgBB}$ ke kelompok ekstrak dosis 100 $\mathrm{mg} / \mathrm{kgBB}$. Hal ini bisa disebabkan rentang dosis yang diberikan terlalu kecil.

Berdasarkan parameter degenerasi sel, ekstrak metanol biji Tamarindus indica tidak memperbaiki kerusakan sel tubulus yang disebabkan aluminium. Dalam penelitian ini, sel tubulus ginjal tikus tampak mengalami degenerasi hidrofik, yang dapat teramati sel mengandung vakuol jernih dalam sitoplasma dan mengalami pembengkakan. Kelima kelompok penelitian menunjukkan skor kerusakan 5 (100\% kerusakan), dan tidak terdapat perbedaan skor kerusakan antarkelompok penelitian baik yang diberikan aluminium, ekstrak maupun larutan campuran aquabides-saline. Hal ini menunjukkan terdapat penyebab yang sama sehingga kelima kelompok menunjukkan skor kerusakan yang sama. Degenerasi sel merupakan perubahan sel akut yang bersifat sementara dan sel dapat kembali pada keadaan normal (reversible) apabila penyebab segera dihilangkan. Dalam penelitian ini dimungkinkan terjadi autolysis pada teknik pembuatan preparat yang menyebabkan gambaran degenerasi sel pada preparat.

\section{KESIMPULAN}

Berdasarkan parameter nekrosis sel ekstrak metanol biji Tamarindus indica memperbaiki kerusakan histopatologi ginjal tikus yang diinduksi aluminium klorida.

\section{DAFTAR PUSTAKA}

Al-Ani IM, Ismail S, Maung KM, Oothuman P, and Al-Mahmood SMA, 2017. Histological study on the protective effects of tamarind seed extract on cobra venom in mice. Asian Journal of Pharmaceutical and Clinical Research. 10(10): 301-305.

Bandawane D, Hivarale M, Mali A, and Mhetre N, 2013. Evaluation of Anti-inflamatory and Analgesic Activity of Tamarind (Tamarindus indica L.) Seeds. International Journal of Pharmacy Pharmaceutical Sciences. 5 (4): 623-629.

Chunglok W, Utaipan T, Somchit N, Lertcanawanichakul $M$, and Sudjaroen Y, 2014. Antioxidant 
and Antiproliferative Activities of Non-Edible Parts of Selected Tropical Fruits. Sains Malaysiana. 43 (5): 689-696.

Dera HSA, 2016. Protective Effect of Resveratrol Against Aluminum Chloride Induced Nephrotoxicity in Rats. Saudi Medical Journal. 37(4): 369-378.

Dolara P, 2014. Occurrence, Exposure, Effects, Recommended Intake and Possible Dietary Use of Selected Trace Compounds (Aluminium, Bismuth, Cobalt, Gold, Lithium, Nickel, Silver). International Journal of Food Sciences and Nutrition. 65(8): 911-924.

Kahtani MAA, Abdel-Moneim AM, and ElSayed WM, 2014. The Influence of Taurine Pretreatment on Aluminum Chloride Induced Nephrotoxicity in Swiss Albino Mice. Histology and Histopathology. 29: 45- 55.

Narwanto MI, Rahayu M, Soeharto S, Nurdiana, dan Widodo M A, 2018. Identifikasi dan Uji In Silico Potensi Anti Inflamasi dan Antioksidan Senyawa Polifenol Ekstrak Metanol Biji Tamarindus indica. Journal of Agromedicine and Medical Science. 4 (1): 13-17.
Razali N, Junit SM, Ariffin A, Ramli NSF, and Aziz AA, 2015. Polyphenols from the Extract and Fraction of $T$. indica Seeds Protected HepG2 Cells Against Oxidative Stress. Complementary and Alternative Medicine. 15: 438.

Samawy ERMA, 2012. Morphological and Histological Study of The Kidneys on The Albino Rats. Al-Anbar Journal of Veterinary Sciences. 5(2): 115-119.

Sundaram MS, Hemshekhar M, Thushara RM, Santosh MS, Kumar SKN, et al, 2014. Tamarind Seed Extract Mitigates the Liver Oxidative Stress in Arthritic Rats. The Royal Society of Chemistry. 5(3): 587597.

Tripathi S, Somashekar BS, Mahdi AA, Gupta A, Mahdi F, et al, 2008. Aluminum-Mediated Metabolic Changes in Rat Serum and Urine: A Proton Nuclear Magnetic Resonance Study. J Biochem Molecular Toxicology. 22(2): 119127.

Vargas-Olvera CY, Sanches-Gonzales DJ, Solano JD, Aguilar-Alonso FA, Montalvo-Munoz F, et al, 2012. Characterization of NDiethylnitrosamine-Initiated and Ferric Nitrilotriacetate-Promoted 
Ekstrak Metanol Biji Asam Jawa (Tamarindus Indica) Memperbaiki Kerusakan Histopatologi... Anang Dwi Atmoko, Al Munawir, Ika Rahmawati Sutejo

$\begin{array}{lr}\text { Renal Cell Carcinoma } & \text { Vignal C, Desreumaux P, and Body-Malapel } \\ \text { Experimental Model and Effect of } & \text { M, 2016. Gut: an Underestimated } \\ \text { a Tamarind Seed Extract Against } & \text { Target Organ for Aluminum. } \\ \text { Acute Nephrotoxicity and } & \text { Morphologie. 1-10. }\end{array}$

Carcinogenesis. Mol Cell Biochem.

369: 105-117. 